I 869. Whitaker, W.- "On the Succession of Beds in the 'New Red' on the South Coast of Devon, and on the Locality of a New Specimen of Hyberodapedon." Quart. Fourn. Geol. Soc., vol, xxv, p. I52.

1887. WOODWARD, H. B.- "Geology of England and Wales," Ed. 2. (New Red Rocks, p. 233; Cretaceous, pp. 39r, 393; Superficial deposits, p. 493.)

1890. WORTH, R. N.-"The Igneous Constituents of the Triassic Breccias and Conglomerates of South Devon." Quart. Fourn. Geol. Soc., vol. xlvi, p. 69 .

\title{
CYCLING EXCURSION FROM WINCHFIELD TO WOKINGHAM.
}

\author{
SATURdAY, APRIL 8TH, I899.
}

Director: H. W. Monckton, F.L.S., F.G.S.

Excursion Secretary: W. P. D. STEBbing, F.G.S.

(Report by The Director.)

Leaving Winchfield a little before half past three, the party cycled to the brick-field on the south-western side of Hazeley Heath, $2 \frac{3}{4}$ miles from the station.

The rather sandy clay worked belongs to the Middle Bagshot Series ; the heath, in fact, is a Middle Bagshot outlier, and it is capped by a gravel, the top being a flat expanse, with a level of a little over $288 \mathrm{ft}$. above Ordnance Datum. The details are clearly shown on Sheet 284 of the New Series Geological Survey Map recently published.

There are numerous gravel-pits, one of which was selected for examination. The gravel was seen to be fairly well stratified with thin beds of sand here and there, the sandy parts frequently showing current bedding. In some places the stratification was less well marked, and often there was a certain amount of contortion and patches of mottled gravel, but these seemed to be always near the surface of the ground. In one section, $7 \mathrm{ft}$. deep, the contorted part extended $5 \mathrm{ft}$. from the surface, whilst close by a roft. section showed no contortion. The gravel consists mainly of sub-angular flints, whose brown colour suggests long exposure to atmospheric agencies, and possibly they have been derived from older drift. There is a good deal of cherty material from the Hythe Beds of the Lower Greensand, whose nearest outcrop is now fifteen miles to the south-east. The locality is on the western margin of the area over which this Hythe Bed material has been distributed.* The Director gave reasons for believing that this and all the gravels about were old

\footnotetext{
* See H. W. Monckton, Quart. Journ. Geol. Soc., vol. xlviii, map on p. 38 . JULY, 1899.$]$
} 
river gravels, ${ }^{*}$ and no one present seemed inclined to dispute the point.

Leaving Hazeley Heath the members crossed the little river Hart and ascended Star Hill on to Hartford Bridge Flats, about $310 \mathrm{ft}$. O.D. A halt was made at a gravel-working near Cooper's Farm, $5^{\frac{1}{2}}$ miles from the start. In composition the gravel is very similar to that of Hazeley Heath, and the Director thought there must be a slip of the pen in Mr. Salter's statement (Proc. Geol. Assoc., vol. xv, p. 272) that "the bulk of the material composing the gravels in this district is derived from Tertiary strata, and but little from the Wealden." The Director thought the sub-angular flints of which the gravel mainly consists were derived from the Chalk, or from older drifts, and he doubted whether any of the material came from Wealden Beds. $t$ There are, no doubt, a fair number of flint pebbles from Bagshot Pebble Beds. A section, $7 \mathrm{ft}$. deep, showed mottled gravel with scarcely a sign of stratification, and there is a somewhat unusual absence of stratification in the gravel all over the top of these flats, and as their level is over $300 \mathrm{ft}$. O.D., they furnish a good example of high-level gravel with but little stratification.

The party then crossed the valley of the Blackwater into Berkshire. and the next halt was at Finchampstead, in Sheet 268 of the Geological Survey Map, New Series.

The green-coloured sands of the Middle Bagshot were seen below East Court, and at the top of the hill a road-section at North Court showed yellow Upper Bagshot sand. Scarcely a sign of bedding is seen in that series, and here and there small patches of green sand were observed. Finchampstead Ridges are capped by gravel at a level of about $33^{\circ} \mathrm{ft}$. O.D. The party cycled, by way of Warren Lodge and the Nine-mile Ride, to some brick-fields between Wellington College and Wokingham, having ridden 12 miles from Winchfield Station.

Up to the present the route had lain over country, which, it is believed, had not previously been visited by the Association, but the brick-fields in the Nine-mile Ride received attention on June 2 Ist, I890. $\neq$

The first pit visited showed a good exposure of the currentbedded Lower Bagshot sand and above it was a laminated clay which is worked for brick-making. This, the Director thought, belonged also to the Lower Bagshot, but Dr. Irving and others hold that it is Middle Bagshot, and in any case it is very near the

* See Proc. Geol. Assoc., vol. xiv, p. 127.

+ By the courtesy of Mr. Monckton, I am permitted to say that in the remarks quoted above, I refer to the Wealden district (not beds), and that I regard some of the earlier drifts of this district as probably of Pliocene age. Hence the sentence would read thus: "The bulk of the material (i.e., the rounded flint pebbles and perhaps the brown sub-angular fints) composing the gravels in the district is derived from Tertiary strata (i.e., Bagshot or perhaps Pliocene Drifts), and but little (such as small quartz pebbles and chert) from the Wealden", district.-A. E. SALTER.

$\ddagger$ Proc. Geol. A ssoc., vol. xi, p. clvi. 
line of division between the two series. The surface of the ground is formed of gravel of variable thickness with a level of about $240 \mathrm{ft}$. O.D., and both the gravel and underlying clay are much contorted. An excellent example of these contorted beds is shown in a photo by the Rev. H. P. Kempthorne, part of which was reproduced in the report of a former excursion,* which was under the direction of Dr. Irving.

On the motion of the President, a cordial vote of thanks to the Director was passed, and the members cycled to Wokingham Station, where they arrived at about 6.30 p.m., the total distance covered having been 15 miles.

\title{
REFERENCES.
}

Geological Survey Map, New Series, Sheets 284, 258 Drift. Price 3s. each. Ditto Old Series, Sheet 8 Drift.

I872. Whitaker, W.- "Geology of the London Basin." Mem. Geol. Survey.

I883. Irving, A.—“Bagshot Strata." Proc. Geol. Assuc., vol, viii, p. 133 .

1886. MonCKTon, H. W., and HeRRies, R. S.—"Bagshot Beds." Quart. Gourn. Geol. Sre., vol, xlii, p. 402.

I890, IRving, A.-"Excursion to Wokingham, etc." Proc. Geol. Assoc., vol. xi, p. clvi.

I892. MoncKToN, H. W.- "Gravels South of the Thames." Quart. Fourn. Geol. Soc., vol. xlviii, p. 29.

\section{EXCURSION TO NEW RAILWAY, WALTON-ON-THE-HILL, AND BETCHWORTH.}

\author{
SATURDAY, APRIL I 5 Th, I 899 . \\ Directors: W. Whitaker, F.R.S., Pres. G.S., and \\ W. P. D. Stebbing, F.G.S. \\ Excutsion Secretary: Bedford MCNeILI, F.G.S. \\ (Refort by Mr. STEBBING.)
}

THE members reached Kingswood at 2.2 p.m., and walked to the cutting on the western side of the tunnel under Walton Heath, in progress for the Chipstead Valley line. At its south-eastern end the cutting showed Chalk covered with pipes of Thanet Sand, and redeposited Woolwich Clay with flint pebbles; near the working face at the north-western end the Thanet Sand seemed to occur in mass. A point of interest, however, in this cutting was the way in which the Chalk had

$$
\text { JuLv, I899.] }
$$

